\title{
RESPONSES OF AN ANTARCTIC KELP GULL Larus dominicanus REPRODUCTIVE POPULATION TO CLIMATE
}

http://dx.doi.org/10.4322/apa.2014.067

\author{
Elisa de Souza Petersen ${ }^{1, *}$, Lucas Krüger ${ }^{1}$, Maria Virginia Petry ${ }^{1}$ \\ ${ }^{1}$ Laboratório de Ornitologia e Animais Marinhos, Universidade do Vale do Rio dos Sinos - UNISINOS, \\ Av. Unisinos, 950, Cristo Rei, CEP 93022-000, São Leopoldo, RS, Braszil \\ *e-mail: elisapetersen@yahoo.com.br
}

\begin{abstract}
The influences of El-Niño over seabird populations have been demonstrated for a great number of species, including Antarctic species. We evaluated the effects of Southern Oscillation Index (an atmospheric component of El-Niño) over a breeding population of Kelp Gulls in Admiralty Bay, King George Island. We counted breeding pairs in all ice-free areas in the 2009/10 and 2010/11 summers, and used past values of the same areas from literature. We found the lower numbers of kelp gull pairs occur at the extreme values of Southern Oscillation Index, the lower and the higher. This is strong evidence of the El-Niño influences on population processes within Admiralty Bay kelp gulls, probably by affecting the decision on breeding or skipping breeding in a given year. Such a situation can affect the population in the long term by reducing their instantaneous breeding success.
\end{abstract}

Keywords: climatic changes, El-Niño Southern Oscillation, King George Island

\section{Introduction}

Climate is the main force driving high-latitude bird populations (Mallory et al., 2009; Croxall et al., 2002). Climate variations can eventually induce breeding adults to abandon their nests or chicks (comprising the main cause of decrease in reproductive success) (Mallory et al., 2009), and affect populations in the long term by reducing adult survival (Rolland et al., 2010) and recruitment rates (Ainley et al., 2005). Egg laying, and size of breeding population can also shift year by year as a response to climate constraints (Croxall et al., 2002; Barbraud \& Weimerskirch, 2006). The Variations of the El-Niño Southern Oscillations are influential over the Antarctic Climatic Oscillations and temperature (Changzheng \& Feng, 2010). Studies demonstrated that the temperatures are not the only important predictor of seabird responses to climate, but also climatic indexes (Rolland et al., 2010). Thus, our objective is to evaluate whether a breeding population of Kelp Gull respond to El-Niño Southern Oscillation Index (SOI).

\section{Materials and Methods}

All the ice-free areas of Admiralty Bay, King George Island (Antarctica) were sampled, excluding the areas near the American Station Copacabana, but including the southern areas of SSSI8 (Figure 1). Censuses were conducted during the 2009/2010 austral summer between November 2009 and March 2010. All breeding pairs were counted, taking in account the active nests, or those that had eggs laid in them. The nests were also mapped with GPS receptors. The ice-free areas were classified in accordance with Sander et al. (2006). The abundance of breeding pairs in past years was used (Jablonski, 1986; Sander et al., 2006) to detect time variation as a response to weather. We get the Southern Oscillation Index (SOI - the atmospheric component of ElNiño) data bank from NOAA (www.noaa.gov). To analyze the response of Kelp Gull pairs to SOI we applied an Analysis of Covariance using a negative binomial distribution model as the number of pairs has a similar distribution using the SPSS $18.0(\alpha=95 \%)$. 


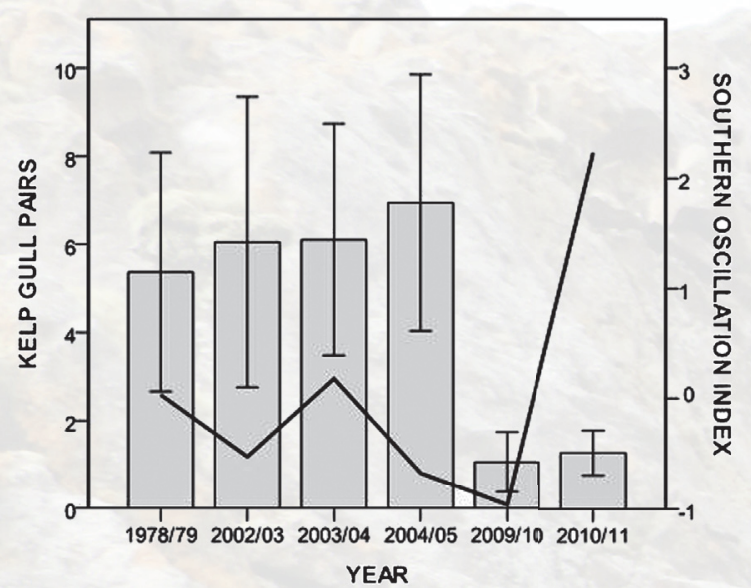

Figure 2. Average number of Kelp Gull pairs (bars) and average Southern Oscillation Index (line) at each summer in Admiralty Bay. Error bars are standard errors.

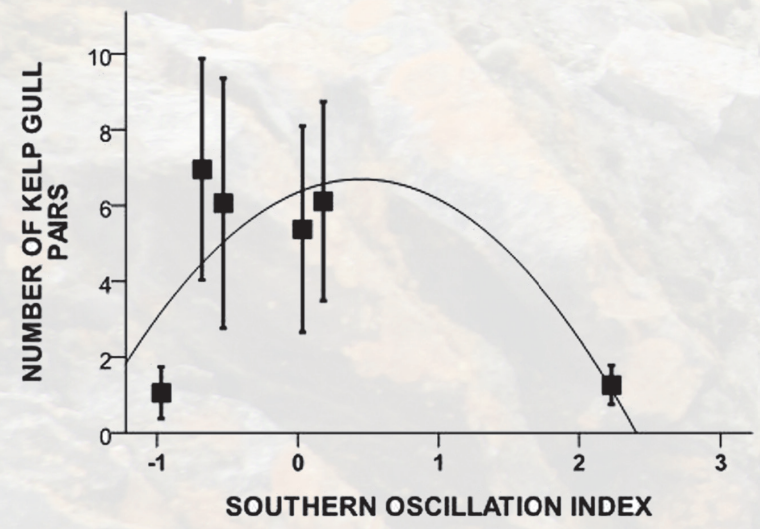

Figure 3. Variation of average number of Kelp Gull pairs in response to the average Southern Oscillation Index. Trend line is a quadratic function represented by the equation $Y=1.6 * X-1.75^{\star} X^{2}+6.34 ; R^{2}=0.62$.

(Lescroël et al., 2009; Beaulieu et al., 2010). One explanation for such changes is the increasing influence of ENSO in Antarctica (Croxall et al., 2002). The 2009/10 summer was the coldest in the last decades (INPE, 2010). We verified in surveys that there were few ice-free areas, reducing the availability or suitability of breeding habitat, but the subsequent summer (2010/11) was warmer providing a

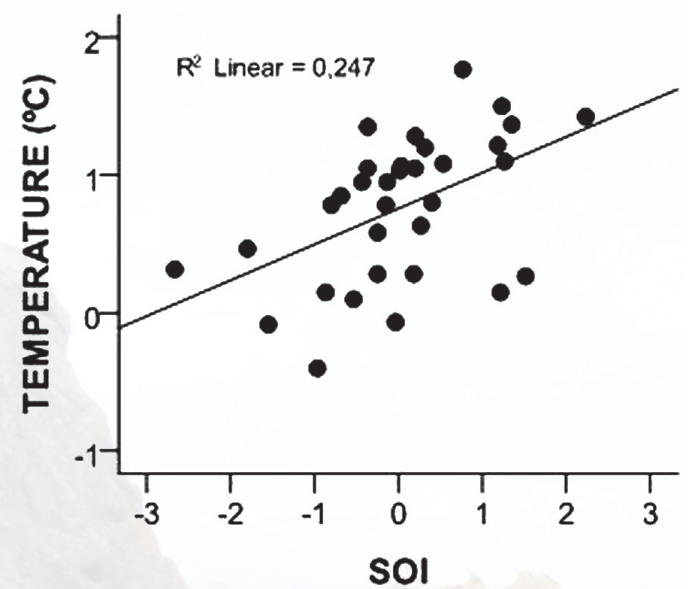

Figure 4. Variation of Temperature as a response to Southern Oscillation Index (SOI).

greater number of ice-free areas, but there were few breeders as a function of high SOI.

The variations of El-Niño have an influence on Antarctic waters and can affect the animal population and ecological processes within populations. In the short term such effect reduces the numbers of breeding pairs and as a consequence the breeding success of the population. In the long term, recruitment rates can be affected, and it may imply in lower growth rates.

\section{Acknowledgements}

This work integrates the National Institute of Science and Technology Antarctic Environmental Research (INCTAPA) that receives scientific and financial support from the National Council for Research and Development (CNPq process: $n^{\circ}$ 574018/2008-5) and Carlos Chagas Research Support Foundation of the State of Rio de Janeiro (FAPERJ $n^{\circ}$ E-16/170.023/2008). The authors also acknowledge the support of the Brazilian Ministries of Science, Technology and Innovation (MCTI), of Environment (MMA) and InterMinistry Commission for Sea Resources (CIRM). 


\section{References}

Ainley, D.G.; Clarke, E.D.; Arrigo, K.; Fraser, W.R.; Kato, A.; Barton, K.J. \& Wilson, P.R. (2005). Decadal-scale changes in the climate and biota of the pacific sector of the southern ocean, 1950s to 1990s. Antarctic Science, 17: 171-182.

Barbraud, C. \& Weimerskirch, H. (2006). Antarctic birds bredd later in response to climate change. PNAS, 103: 6248-6251.

Beaulieu, M.; Dervaux, A.; Thierry, A.; Lazin, D.; Maho, Y.L.; Ropert-Coudert, Y.; Spée, M.; Raclot, T. \& Ancel, A. (2010). When sea-ice clock is ahead of Adelié Peguins' clock. Functional Ecology, 24: 93-102.

Changzheng, L. \& Feng, X. (2010). The relationship between the canonical ENSO and the phase transitions of the Antarctic oscillation at the quasi-quadrennial timescale. Acta Oceanologica, 29: 26-34.

Croxall, J.P.; Trathan, P.N. \& Murphy, E.J. (2002). Environmental change and Antarctic seabird populations science. Science, 297: 1510-1514.

Instituto Nacional de Pesquisas Espaciais - INPE. (2010). Available from: <http://www.antarctica.cptec.inpe.br>. (accessed: 27 abr. 2010).

Jablonski, B. (1986). Distribution, abundance and biomass of a summer community of birds in the region of the Admiralty Bay (King George Island, South Shetland Islands, Antarctica) in 1978/1979. Polish Polar Research, 7: 217-260.

Lescroël, A.; Dugger, K.M.; Ballard, G. \& Ainley, D.G. (2009). Effects of individual quality, reproductive success and environmental variability on survival of a long-lived seabird. Journal Animal Ecology, 78: 798-806.

Mallory, M.L.; Gaston, A.J.; Forbes, M.R. \& Gilchrisr, H.G. (2009). Influence of weather on reproductive success of northern fulmars in the Canadian high Arctic. Polar Biology, 32: 529-538.

Rolland, V.; Weimerskirch, H. \& Barbraud, C. (2010). Relative influence of fisheries and climate on the demography of four albatross species. Global Change Biology, 16: 1910-1922.

Sander, M.; Carneiro, A.P.B.; Mascarello, N.E.; Santos, C.R.; Costa, E.S. \& Balbão, T.C. (2006). Distribution and status of the kelp gull, Larus dominicanus Lichtenstein (1823), at Admiralty Bay, King George Island, South Shetland, Antactica. Polar Biology, 29: 902-904. 